Discussion Paper No. 982

\author{
WHAT DETERMINES \\ FINANCIAL LITERACY \\ IN JAPAN? \\ Yoshihiko Kadoya \\ Mostafa Saidur Rahim Khan
}

October 2016

The Institute of Social and Economic Research

Osaka University

6-1 Mihogaoka, Ibaraki, Osaka 567-0047, Japan 


\title{
What Determines Financial Literacy in Japan?*
}

\author{
Yoshihiko Kadoya ${ }^{\dagger}$
}

Mostafa Saidur Rahim Khan

\begin{abstract}
This study aims to determine the factors that affect financial literacy in Japan using data from Osaka University's Preference Parameter Study in Japan. We examined fourteen variables covering respondents' demographic, socio-economic, and psychological backgrounds drawn from social learning, consumer socialization, and psychology theories of learning. The results indicate that the demographic factors of gender, age, and education; the socio-economic factors of income and occupation; and the psychological factor of perceptions about future significantly affect the level of financial literacy. We checked the robustness of results using a different measure of financial literacy, which also confirmed our findings. The results emphasize the need for a formal financial education and social contact to boost financial literacy levels in Japan.
\end{abstract}

Keywords: financial literacy, household, finance

JEL codes: D14, G02

\footnotetext{
${ }^{*}$ This research used micro data from the Preference Parameters Study of Osaka University's 21 st Century COE Program 'Behavioral Macrodynamics Based on Surveys and Experiments' and its Global COE project 'Human Behavior and Socioeconomic Dynamics'. We acknowledge the program/project's contributors: Yoshiro Tsutsui, Fumio Ohtake, and Shinsuke Ikeda. We thank Nobuyoshi Yamori, Noriyoshi Yanase, and the other seminar participants at Japan Institute of Life Insurance. This work was supported by JSPS KAKENHI Grant Number 15K17075, 15KK0083, and RISTEX, JST..

${ }^{\dagger}$ School of Economics, Hiroshima University, 1-2-1 Kagamiyama, Higashi Hiroshima, Hiroshima 7398525 JAPAN Email: ykadoya@hiroshima-u.ac.jp

\$ Graduate School of Economics, Nagoya University, Furo-cho, Chikusa, Nagoya 4648601, Japan. Email: saidur_rahim@yahoo.com
} 


\section{INTRODUCTION}

Households now need more financial knowledge in their decision making because the current marketplace is more risky and globalized (Lusardi and Mitchell 2011a). Although social security and public health provisions are developing, people need financial literacy to determine retirement savings and costs for healthcare and long-term care (Banks 2010) and to improve the practicality and utility of savings, investment, retirement planning, wealth accumulation, and stock market participation decisions (Bernheim and Garret 2003; Van Rooij, Lusardi, and Alessie 2011, 2012; Lusardi and Mitchell 2011b; Sekita 2013). Financial literacy improves retirement planning (Lusardi and Mitchell 2011b), the ability to save and invest in complex financial assets (Van Rooij, Lusardi, and Alessie 2011), and wealth accumulation through better retirement planning, savings plans, and stock market investments (Van Rooij, Lusardi, and Alessie 2012). While most evidence comes from the American context, some research exists for the Netherlands (Alessie, van Rooij, and Lusardi 2011), Japan (Sekita 2011, 2013), Canada (Boisclair, Lusardi, and Michaud 2014), Switzerland (Brown and Graf 2013), and Australia (Agnew, Bateman, and Thorp 2013). Although many previous studies focused on the link between financial literacy and savings and investment decisions, relatively few examine the factors that affect financial literacy.

Financial literacy means understanding the value of money and how to maximize the benefits of money utilization. Many institutions and authors provided different definitions of financial literacy, but their inherent meanings are similar. The US Financial Literacy and Education Commission of 2007 and the Organization for Economic Co-operation and Development (OECD) summarized the previous definitions as the ability and awareness to use knowledge and skills to manage financial resources to achieve maximum financial well-being 
(OECD 2013; Financial Literacy and Education Commission 2007). Our study defines financial literacy as the ability to understand the implications of interest, inflation, risks, and diversification. This definition provides the benefit of measurability, which enables researchers to relate financial literacy with a country's demographic and socio-economic environment. Although financial literacy is an important issue that affects household decisions on savings and investment, there is still no nationwide comprehensive study on the determinants of financial literacy in Japan.

There are several existing theories related to financial literacy. Social learning theory and the theory of consumer socialization grew from theories about learning processes in a society. Social learning theory argues that as social entities, people learn from observing the behavior and actions of others (Bandura and Walters 1977). Several studies used social learning theory to investigate financial behavior (Hira 1997; Martin and Bush 2000). The theory of consumer socialization argues that children learn the consumption-related knowledge and skills required to live capably in society from parents, schools, mass media, and peers (Ward 1974; Moschis and Churchill 1978). Some empirical evidence showed an important relationship between financial knowledge and behavior and social learning opportunities (Gutter, Garrison, and Copur 2010). Both theories emphasize that people learn financial skills from society, and directly imply that knowledge and attributes of the people with whom subjects live significantly affects financial literacy. Lachance and Choquette-Bernier (2004) found that observation, parental communication, and learning through error contributed to students' acquisition of financial knowledge. Koonce et al. (2008) showed that society, family, peers, and media, contributed people's financial literacy. Economic and financial theories based on psychology and behavior emphasize that behavioural patterns affect financial decisions (Kahneman and Tversky 1979). In 
a recent study, Gill and Prowse (2015) argued that learning is positively related to cognitive ability, agreeability, and emotional stability. Several studies investigated the role of psychology in determining financial literacy and showed that confidence, trust, financial satisfaction, orientation for future, anxiety about life in the future, and other factors shape the acquisition of financial knowledge (Kadoya and Khan 2016; Arellano, Cámara, and Tuesta 2014; Murphy 2013).

The study of financial literacy in Japan is important for several reasons. Although financial literacy is associated with financial wellbeing, the level of financial literacy worldwide, including Japan, is not so high (Lusardi and Mitchell 2011a; Sekita 2011; Hussein and Kalli 2009; Jappelli 2009; Boisclair, Lusardi, and Michaud 2014). Therefore, it is important to examine the factors responsible for financial literacy to determine why financial literacy in Japan is at its low level. Moreover, several studies found that Japan is culturally distinct from other countries and that Japanese people have different of savings and investment behaviors (Chui, Titman, and Wei 2010). Japanese people tend toward risk aversion, passivity, collectivism, and low individualism, which research into their effect on financial literacy in Japan.

Our study examines the factors affecting the level of financial literacy among Japanese people using several demographic, socio-economic, and psychological factors to investigate their effect on financial literacy. Our study offers at least two contributions to the existing literature. First, to the best of our knowledge, this is the first study that explores the demographic, economic, and psychological factors in financial literacy in Japan, and second, this study seeks to explain why financial literacy is historically low among Japanese people.

Rest of the paper is organized as follows. Sections 2 and 3 describe the data and define the variables, respectively. Section 4 describes the methodology and section 5 reports the 
empirical results. Section 6 shows robustness of results. Section 7 discusses the results in the context of existing research and section 8 concludes the paper.

\section{METHODOLGOY}

\section{Variables and Measurements}

\section{Dependent Variable}

The most important aspect of a study examining the determinants of financial literacy is an appropriate measure of financial literacy. Lusardi and Mitchell $(2007,2008)$ measured financial literacy using three questions; Van Rooij, Lusardi, and Alessie (2011) used five questions; and Stango and Zinman (2009) used only one question. While the number of questions in each of these studies differs, most recent studies (Sekita 2013) followed Lusardi and Mitchell's (2007, 2008) methodology. We do the same, but use four questions to measure the dependent variable, financial literacy, as respondents' ability to understand basic financial calculations, inflation, risks, and the pricing behavior of financial securities. Respondents answered the following questions with a set of options

1. Suppose you had $¥ 10,000$ in a savings account, with an interest rate of $2 \%$ per year, and you never withdraw money or interest payments. After 5 years, how much would you have in this account?

$\square$ More than $¥ 10,200 \square$ Exactly $¥ 10,200 \square$ Less than $¥ 10,200 \square$ Do not know $\square$ Refuse to answer

2. Imagine that the interest rate on your savings account is $1 \%$ per year and inflation is $2 \%$ per year. After 1 year, how much would you be able to buy with the money in this account?

$\square$ More than today $\square$ Exactly the same $\square$ Less than today $\square$ Do not know $\square$ Refuse to answer 
3. Please indicate whether the following statement is True or False: "Buying a company stock usually provides a safer return than a stock mutual fund."

$\square$ True $\square$ False $\square$ Do not know $\square$ Refuse to answer

4. If the interest rate falls, what should happen to bond prices?

$\square$ Rise $\square$ Fall $\square$ Stay the same $\square$ None of the above $\square$ Do not know $\square$ Refuse to answer

The first two questions measure respondents' ability to understand basic financial calculations, and the last two questions are more related to financial instruments to measure respondents' ability to understand the basic nature and movement of financial securities' prices.

We assigned one point to each correct answer and did not deduct points for a wrong answer. We then use the number of correct answers as the respondent's level of financial literacy. This process of measuring financial literacy is unweighted and thus does not put more weight on difficult questions. Our alternative measure of financial literacy assigns one point for each correct answer and deduct points for each wrong answer; it also puts more weight on the last two questions. Sekita (2013) also used both weighted and unweighted methods to examine the relationship between financial literacy and wealth accumulation, and found that both measures produced similar results. While measurement issues do not seem to affect the implications of the results, we used both measures of financial literacy to check the robustness of our results.

Table 2 reports the distribution of the financial literacy scores by age, gender, and education. Financial literacy increases with age up to a certain level, after which it begins to fall: middleaged respondents had the highest financial literacy, though older respondents had more financial literacy than the younger respondents. Male respondents were more financially literate than female respondents. The level of financial literacy differed significantly depending on the level of education. More educated respondents had high financial literacy scores. We grouped 
education into three levels: up to college level (12 years of education), graduate level (16 years of education), and post graduate level (more than 16 years of education). Financial literacy among respondents with more than 16 years of education was much higher than for the other groups.

[Insert Table 2 about here]

\section{Independent variables}

To explain the determinants of financial literacy we include variables related to demographics, socio-economics, and psychological background, in line with the theories discussed in the introduction. Table 3 reports the variables used in this study.

[Insert Table 3 about here]

Several studies found that financial literacy varies by gender (Kadoya and Khan 2016; Van Rooij, Lusardi, and Alessie 2011; Alessie et al. 2013; Hung, Yoong, and Brown 2012; Atkinson and Messy 2012; Sekita 2011; Lusardi and Mitchell 2008). Kadoya and Khan (2016) and Sekita (2011) report that women in Japan score lower financial literacy. While women had nearly equivalent scores for the basic financial literacy questions, they scored significantly lower for complex questions related to risk and diversification. However, it is difficult to explain these gender differences. The social learning process could partially explain women's lower financial literacy. Women, particularly married women, have less scope than men to learn socially and from experience, which could lead to difficulty in understanding financial issues. Nevertheless, this theory cannot explain why single, educated women, who more opportunities for social learning have lower scores (Mahdavi 2012). We thus include the gender variable in this study.

Age is an important determinant because people learn from previous mistakes (Lachance and Choquette-Bernier 2004; Martin and Oliva 2001) and eventually become more 
knowledgeable over time. However, Lusardi and Mitchell (2014) outlined a theoretical framework in which they argued that a hump-shaped lifecycle of financial literacy exits. Other studies also showed a non-linear relationship between age and financial literacy, as evident by lower financial literacy among younger people and older people (Lusardi and Mitchell 2011b; Lusardi, Mitchell, and Curto 2010). The initial increase in financial literacy could come from experience, while the subsequent decline could be due to a decrease in cognitive abilities (Agarwal et al. 2009). We include the age variable to explore the relationship between age and financial literacy in Japan.

Respondents' and their spouses' level of education has a direct impact on financial literacy. Because more educated people have more opportunities to take courses related to money management, we expect that they will be more financially literate (Lusardi and Mitchell 2011b, 2014). Psychological theories emphasizing cognitive ability could explain the empirically evident relationship between education and financial literacy (Gill and Prowse 2015; Lusardi, Mitchell and Curto 2010). Danes and Haberman (2007) provided evidence that taking a financial planning curriculum contributed positively to students' financial literacy. Social learning theories, on the other hand, could explain why the education level of a spouse and parents affects respondents' financial literacy. Empirical research shows that people learn from their surroundings, particularly from parents (Pinto, Parente, and Mansfield 2005). People with educated parents and spouses could learn from their knowledge and experience (Mahdavi 2012). To accommodate these dimensions of education, we included respondents' education, spouse's education, and parents' education. 
Social learning process implies that having a spouse provides more opportunities to share and gather experiences, which could improve financial literacy. Therefore, we include the variable "spouse."

Social learning and consumer socialization theories imply that employment status significantly affects knowledge acquisition. People who are employed and have more opportunities to learn about financial issues from the workplace should be more financially literate. Lusardi and Mitchell (2011a) found that employed people had higher financial literacy worldwide. Occupations could also significantly affect financial literacy. An occupation that requires an understanding economic and financial aspects provides more scope for people to achieve financial literacy. Our study used "finance and insurance" as the occupation that could positively affect financial literacy.

Previous studies also provide evidence that household income and balance of financial assets are related to financial literacy (Lusardi and Tufano 2009; Guiso and Jappelli 2008). Economic factors create a link between income and assets and financial assets. People who earn more income and hold more assets need to understand how to use money to maximize their future benefits. Thus, we included income and asset variables and assume that respondents with more income and assets will be more financially literate.

We include three behavioral variables in our study: future orientation, current state of financial satisfaction, and anxiety about life in old age. A psychological orientation toward the future could affect the acquisition of financial literacy (Howlett, Kees, and Kemp 2008). People who emphasize the present have low incentives to acquire financial literacy to maximize future financial benefits. This study used the question, "Since the future is uncertain, it is a waste to think about it" to measure respondents' orientation for future. Our second behavioral variable, 
current state of financial satisfaction, also affects financial literacy (Murphy 2013). We measure financial satisfaction according to subjective responses to the question, "How satisfied you are with the current financial situation of your family?" Finally, our third behavioral variable, anxiety about life in old age could also motivate people to acquire more financial knowledge about savings and retirement planning to make life during old age more secure.

\section{Data}

We used micro data from the Preference Parameters Study of Osaka University's $21^{\text {st }}$ Century Center of Excellence (COE) Program, "Behavioral Macrodynamics Based on Surveys and Experiments" and its Global COE project, "Human Behavior and Socioeconomic Dynamics." The data were collected with a nation-wide survey between December 2011 and May 2012 using visits and placement surveys. The study applied two-stage stratified random sampling of this data: first, we divided Japan's prefectures into 10 regional blocks: Hokkaido, Tohoku, Kanto, Koshinetsu, Hokuriku, Tokai, Kinki, Chugoku, Shikoku, and Kyusyu; and we then subdivided each region into four strata: government-designated major cities, cities with populations of more than 100,000 , cities with populations of less than 100,000, and towns and villages. The response rate was 93.9 percent. The fact that the project was a panel survey explains the high response rate. The data of respondents' financial literacy and education were from the wave 2010 and 2011 respectively, because these questions weren't asked in the 2012 wave. We selected the subjects with no missing variables and the current study uses a sample of 1,948 respondents.

Table 1 summarizes the descriptive statistics of the variables used in the study. The mean value of financial literacy is 0.48 , indicating that respondents had a low ability to respond correctly to the financial literacy questions. On average, respondents could answer two questions 
correctly out of four. In terms of demographics, male respondents were somewhat higher in numeracy than the female respondents. The respondents were on average 49.31 years old, with a minimum age of 24 and a maximum age of 69 . Most respondents were married. We measured respondents' socio-economic features using their level of education and that of their spouses and parents. Japan traditionally has a high level of education, which is reflected in our study. Respondents on average had more than 13 years of education, meaning that they attained an above college-level education. Respondents' spouses also attained similar levels of education. Respondents' parents attained an average of 10.84 years of education, with fathers' education levels slightly higher than that of mothers. Although high, household income and asset holdings showed some degree of disparity among respondents. Respondents' average income was JPY $6,662,640$, with a minimum income of JPY 1,000,000 and a maximum income of JPY 20,000,000. Average asset holdings were JPY 20,920,000, ranging from a minimum of JPY $2,500,000$ and a maximum of JPY $100,000,000$. In terms of psychological features, respondents were moderately fatalist, believing that the future is uncertain and thinking about it is a waste of time. Respondents were also moderately satisfied with their current financial condition. Finally, their mean anxiety was 3.47 , which is moderately high on a five-point scale.

[Insert Table 1 about here]

\section{Model}

This study used a linear regression model to investigate the determinants of financial literacy in Japan. In the regression, financial literacy is the dependent variable, and there are fourteen independent variables for respondents' demographic, socio-economic, and psychological features. The regression equation is as follows: 
Financial Literacy (fliteracy) $=\alpha+\beta_{1}$ age $+\beta_{2}$ gender $+\beta_{3}$ spouse +

$\beta_{4}$ education $_{\text {respondents }}($ educ $)+\beta_{5}$ education $_{\text {spouse }}($ seduc $)+$

$\beta_{6}$ education $_{\text {father }}($ feduc $)+\beta_{7}$ education $_{\text {mother }}($ meduc $)+\beta_{8}$ household income +

$\beta_{9}$ household assets $+\beta_{10}$ employment status (emplstatus) $+\beta_{11}$ occupation +

$\beta_{12}$ future orientation $++\beta_{13}$ Financial satisfaction (finsatisfaction) $+\beta_{14}$ anxiety

Since distribution of financial literacy by age in Table 2 indicates a nonlinear relationship between financial literacy and age, we examined the relationship more closely by adding an age ${ }^{2}$ variable in model 2. A positive coefficient on age would indicate a positive relationship between age and financial literacy, and negative coefficient on age would indicate a nonlinear relationship. Financial Literacy (fliteracy) $=\alpha+\beta_{1}$ age $+\beta_{2}$ age $2+\beta_{3}$ gender $+\beta_{4}$ spouse + $\beta_{5}$ education $_{\text {respondents }}(e d u c)+\beta_{6}$ education $_{\text {spouse }}($ seduc $)+$ $\beta_{7}$ education $_{\text {father }}($ feduc $)+\beta_{8}$ education $_{\text {mother }}($ meduc $)+\beta_{9}$ household income + $\beta_{10}$ household assets $+\beta_{11}$ employment status (emplstatus $)+\beta_{12}$ occupation + $\beta_{13}$ future orientation $+\beta_{14}$ Financial satisfaction (finsatisfaction) $+\beta_{15}$ anxiety

\section{EMPIRICAL RESULTS}

Table 4 summarizes the findings on the determinants of financial literacy in Japan. The $\mathrm{F}$ statistic demonstrates the overall validity of the model. We show that demographic features such as gender, age, and education affect financial literacy considerably. Among the demographic variables, gender appears to be the most significant, indicating that male respondents are significantly more financially literate than female respondents, which is in line with the 
descriptive statistics in Table 1. Age and education were also significant determinants of financial literacy in Japan. Both are positively related to financial literacy, indicating that younger and less educated respondents are less financially literate. However, age does not have a linear relationship to financial literacy, meaning that age is positively related to financial literacy up to a certain point, after which the relationship does not hold true. Although marital status did not affect financial literacy significantly, the spouse's education is positively related to financial literacy, suggesting that more educated spouses help their counterparts attain a higher level of financial literacy. The education of respondents' parents did not affect financial literacy, contrary to our hypothesis. We used several economic variables to examine the link between economic condition and financial literacy. As we expected, both income and assets are positively related to financial literacy. Although respondents' employment status does not contribute to financial literacy, occupation was significantly positive. This means that respondents who have exposure to a financial environment in the workplace tend to be more financially literate. We used three psychological variables in our model, of which orientation toward the future was negatively related to financial literacy. The coefficient indicates that respondents who consider thinking about future a waste of time tend to be less financially literate. However, we did not find any evidence that respondents' satisfaction with their present financial situation or anxiety about life in old age influenced financial literacy.

[Insert Table 4 about here]

\section{Robustness checks}

We checked the robustness of the results using an alternative measure of financial literacy that puts more weight on the questions of risks diversification and pricing behavior. The term weighted financial literacy (fliteracy_w) denotes financial literacy measured by the alternative 
method with the same linear regression model. The results in Table 5 show that as in the unweighted measure of financial literacy, the weighted measure is also affected by factors such as gender, age, respondents' and spouses' education, income, assets, occupation, and orientation toward the future. Since the effect and statistical significance of the variables are similar for both the weighted and unweighted measures of financial literacy, we conclude that issues related to measuring financial literacy do not create biases in the estimation.

[Insert Table 5 about here]

Endogeneity could affect the OLS regression coefficients reported in Table 4, likely due to the asset variable. It is possible that asset holdings can increase financial literacy, or that financial literacy can increase asset holding. To control this reverse causality between assets and financial literacy, we used asset inheritance from parents as an instrument for assets. Asset inheritance is a dummy variable equal to 1 if respondents received at least five million yen from their parents and 0 otherwise. Table 6 reports the regression coefficients for Models 1 and 2, which shows that the positive effect of assets on financial literacy no longer exists using this instrument. However, effect of other variables remains almost the same.

[Insert Table 6 about here]

\section{DISCUSSION}

Previous studies investigated the need for financial literacy to improve household decisions such as savings, retirement planning, and investment (Bernheim and Garret 2003; Van Rooij, Lusardi, and Alessie 2011, 2012, Lusardi and Mitchell, 2011; Sekita 2013; Boisclair, Lusardi, Michaud 2014). However, few studies examine the reverse association. Our study provides evidence of the determinants of financial literacy in Japan. We based the study on three theories related to the learning process: social learning theory, consumer socialization theory, and 
psychological theory. We identified fourteen variables that could affect financial literacy and grouped them into demographic, socio-economic, and psychological factors. Among the demographic factors, we found that gender, age, and education significantly affect financial literacy in Japan. Our finding that male respondents are more financially literate than female respondents is also supported by previous studies (Kadoya and Khan 2016; Lusardi, Alessie, and Van Rooij 2012; Hung, Yoong, and Brown 2012; Atkinson and Messy 2012; Sekita 2011; Lusardi and Mitchell 2008). Fonseca et al. (2010) argued that the gender gap in financial literacy cannot be explained by the characteristics of men and women but rather by how literacy is produced. Apart from gender, age was also positively related to financial literacy. However, we found that the relationship is not monotonous; rather, financial literacy peaked in middle age and began to decline thereafter. Although previous studies argue that people that learn through mistakes and over time become more knowledgeable (Lachance and Choquette-Bernier 2004; Martin and Oliva 2001), Lusardi and Mitchell (2014) argued that the relationship is not so linear. Lusardi and Mitchell (2011b) and Lusardi, Mitchell, and Curto (2010) also found a non-linear relationship between age and financial literacy. Education is an important variable with the most direct influence on financial literacy, which is supported by psychological theory that emphasizes cognitive ability (Gill and Prowse 2015; Lusardi, Mitchell and Curto 2010), while the influence of spouses' and parents' education is supported by social learning theory (Pinto Parente, and Mansfield 2005; Mahdavi 2012). We found that respondents' and spouses' education have a positive impact on financial literacy, while parents' education does not. Although our findings related to respondents and their spouse's education are supported by theory and empirical evidence, the insignificant impact of parents' education was contrary to our hypothesis. We argue that the age structure of respondents and their parents could explain this 
finding. Since average age of the respondents in this sample was more than 49 years, they could have less interaction with their parents. Moreover, parents from the older generations are themselves less financially educated, which gave their children fewer opportunities to learn through socialization. Among the demographic variables, marital status did not influence financial literacy, though spouse's education did, which implies that social learning theory works only when respondents' have capable spouses.

In terms of socio-economic background, both income and assets have significantly positive effects on financial literacy, in line with previous studies (Lusardi and Tufano 2009; Guiso and Jappelli 2008). We also examined employment status and type of occupation to understand whether work experience is related to financial literacy. Although employment status did not have an effect, occupation did have a significant impact. Respondents with working experience in the finance area were more financially literate than others. However, Lusardi and Mitchell (2011b) reported that financial literacy was higher among employed respondents in their sample, our findings suggest that employment status itself did not enhance financial knowledge; rather, work experience in a relevant field improves financial knowledge.

We also looked at psychological factors to investigate whether respondents' behavior influenced financial literacy. A focus on the future strongly influenced respondents' acquisition of financial knowledge. Those who consider thinking about the future as a waste of time were less financially literate. Perceptions about the future is also related to time discount factors and financial literacy (Howlett, Kees, and Kemp 2008). The other two factors, level of financial satisfaction and anxiety about life in old age, did not have a significant influence on financial literacy. 
The results did not change after checking the robustness using a weighted financial literacy score instead of the original unweighted score. We also checked for endogeneity problems from the potential reverse causality of the asset variable. Using an IV regression model, we found that the positive effect of assets on financial literacy disappears, while the effect of the other variables remain the same.

Our study has some limitations that affect the interpretations of our results and open avenues for future research. First, although we checked the robustness of our findings using a weighted measure of financial literacy, there is no consensus on how to measure financial literacy. Previous studies report that financial literacy scores vary depending on the questions in the questionnaire (Hung, Parker, and Yoong 2009; Moore 2003; Mandell 2007). Second, although we used fourteen variables representing demographic, social-economic, and psychological factors, we did not have the data available to examine respondents' area of education. Third, selfreported subjective anxiety and financial satisfaction levels might be somewhat misleading. Some people tend to make extreme choices (i.e., choosing 1 or 5 on a five-point scale), while others prefer to make moderate choices (i.e., 3), which affect our results.

Overall, the results of our study suggest that socialization and family orientation have a profound impact on the acquisition of financial literacy in Japan, which could improve their savings, retirement planning, and investment decisions. 


\section{REFERENCES}

Agarwal, Sumit, John C. Driscoll, Xavier Gabaix, and David Laibson. 2009. The Age of Reason: Financial Decisions over the Lifecycle. Brookings Papers on Economic Activity, 2009 (2): $51-117$.

Arellano, Alfonso, Noelia Cámara, and David Tuesta. 2014. The Effect of Self-Confidence on Financial Literacy. BBVA Research Working Paper, 14/28.

Agnew, Julie R. Bateman, Hazel, and Thorp, Susan. 2013. Financial Literacy and Retirement Planning in Australia. Numeracy, 6 (2): 7.

Alessie, Rob, Maarten Van Rooij, and Annamaria Lusardi. 2011. Financial Literacy and Retirement Preparation in the Netherlands. Journal of Pension Economics and Finance, 10 (4): $527-46$.

Alessie, Rob, Tabea Bucher-Koenen, Annamaria Lusardi, and Maarten van Rooij. 2013. Gender, Confidence and Financial Literacy. Neuro Psycho Economics Conference Proceedings.

Atkinson, Adele, and Flore-Anne Messy. 2012. Measuring Financial Literacy: Results of the OECD / International Network on Financial Education (INFE) Pilot Study. OECD Working Papers on Finance, Insurance and Private Pensions, 15. OECD Publishing.

Bandura, Albert, and Richard H. Walters. 1977. Social Learning Theory. New York: General Learning Press.

Banks, James. 2010. Cognitive Function, Financial Literacy and Financial Outcomes at Older Ages: Introduction. The Economic Journal, 120 (548): F357-F362.

Bernheim, B. Douglas, and Daniel M. Garrett. 2003. The Effects of Financial Education in the Workplace: Evidence from a Survey of Households. Journal of Public Economics, 87 (7): $1487-1519$ 
Boisclair, David, Annamaria Lusardi, and Pierre-Carl Michaud. 2014. Financial Literacy and Retirement Planning in Canada. Journal of Pension Economics and Finance, DOI: http://dx.doi.org/10.1017/S1474747215000311

Brown, Martin, and Roman Graf. 2013. Financial Literacy and Retirement Planning in Switzerland. Numeracy, 6 (2): 6.

Chui, Andy C.W., Sheridan Titman, and K.C. John Wei. 2010. Individualism and Momentum Around the World. The Journal of Finance, 65 (1): 361-392.

Hira, Tahira K. 1997. Financial Attitudes, Beliefs, and Behaviours: Differences by Age. Journal of Consumer Studies and Home Economics, 21 (3): 271-290.

Danes, Sharon M., and Heather Haberman. 2007. Teen Financial Knowledge, Self-efficacy, and Behavior: A Gendered View. Journal of Financial Counselling and Planning, 18 (2), 48-60.

Fonseca, Raquel, Kathleen J. Mullen, Gema Zamarro, and Julie Zissimopoulos. 2010. What Explains the Gender Gap in Financial Literacy? The Role of Household Decision-Making. Working paper, WR-762, Rand Corporation.

Howlett, Elizabeth, Jeremy Kees, and Elyria Kemp. 2008. The Role of Self-Regulation, Future Orientation, and Financial Knowledge in Long-term Decisions. Journal of Consumer Affairs, 42 (2): $223-242$.

Hung, Angela, Joanne Yoong, and Elizabeth Brown. 2012. Empowering Women Through Financial Awareness and Education. OECD Working Papers on Finance, Insurance and Private Pensions, No. 14, OECD.

Hung, Angela, Andrew M. Parker, and Joanne Yoong. 2009. Defining and Measuring Financial Literacy. RAND Labor and Population Working Paper, WR-708. 
Gill, David, and Victoria L. Prowse. 2015. Cognitive Ability, Character Skills, and Learning to Play Equilibrium: A level-k Analysis. Available at SSRN: http://ssrn.com/abstract=2448144. Guiso, Luigi, and Tullio Jappelli. 2008. Financial Literacy and Portfolio Diversification. EUI Working Paper, (ECO 2008/31), Florence, Italy: European University Institute.

Gutter, Michael S., Selena Garrison, and Zeynep Copur. 2010. Social Learning Opportunities and the Financial Behaviors of College Students. Family and Consumer Sciences Research Journal, 38 (4): 387-404.

Jappelli, Tullio. 2009. Economic Literacy: An International Comparison. CSEF Working Paper No. 238. Salerno, Italy: Center for Studies in Economics and Finance.

Kadoya, Yoshihiko, and Mostafa Saidur Rahim Khan. 2016. Can Financial Literacy Reduce Anxiety About Life at the Old Age? RIETI Discussion Paper Series 16-E-076, The Research Institute of Economy, Trade and Industry, Japan.

Kahneman, Daniel, and Amos Tversky. 1979. Prospect Theory: An Analysis of Decision Under Risk. Econometrica, 47(2): 263-291.

Koonce, Joan C., Yoko Mimura, Teresa A. Mauldin, A. Michael Rupured, and Jenny Jordan. 2008. Financial Information: Is it Related to Savings and Investing Knowledge and Financial Behavior of Teenagers. Journal of Financial Counseling and Planning, 19 (2): 1928.

Lachance, Marie J., and Nadia Choquette-Bernier. 2004. College Students' Consumer Competence: A Qualitative Exploration. International Journal of Consumer Studies, 28 (5): 433-442. 
Lusardi, Annamaria, and Olivia S. Mitchell. 2007. Financial Literacy and Retirement Preparedness: Evidence and Implications for Financial Education. Business Economics, 42 (1): $35-44$.

Lusardi, Annamaria, and Olivia S. Mitchell. 2008. Planning and Financial Literacy: How do Women Fare? American Economic Review, 98: 413-417.

Lusardi, Annamaria, and Olivia S. Mitchell. 2011a. Financial Literacy Around the World: An Overview. Journal of Pension Economics and Finance, 10 (4): 497-508.

Lusardi, Annamaria, and Olivia S. Mitchell. 2011b. Financial Literacy and Retirement Planning in the United States. Journal of Pension Economics and Finance, 10 (4): 509-525.

Lusardi, Annamaria, and Olivia S. Mitchell. 2014. The Economic Importance of Financial Literacy: Theory and Evidence. Journal of Economic Literature, 52 (1): 5-44.

Lusardi, Annamaria, Olivia S. Mitchell, and Vilsa Curto. 2010. Financial Literacy Among the Young: Evidence and Implications for Consumer Policy. The Journal of Consumer Affairs, 44 (2): 358-380.

Lusardi, Annamaria, and Peter Tufano. 2009. Debt Literacy, Financial Experiences, and Overindebtedness. National Bureau of Economic Research Working Paper, 14808.

Mahdavi, Mahnaz. 2012. Financial Literacy among Educated Women: Room for Improvement. Working Paper, Smith College.

Mandell, Lewis. 2007. Financial Literacy of High School Students. In Handbook of Consumer Finance Research, edited by J.J. Xiao (163-183). New York, NY: Springer.

Martin, Craig A., and Alan J. Bush. 2000. Do Role Models Influence Teenagers' Purchase Intentions and Behavior. Journal of Consumer Marketing, 17 (5): 441-454. 
Martin, Allen, and Juan Carlos Oliva. 2001. Applications of Social Learning and Cognitive Learning Developmental Theories. Journal of Family and Consumer Sciences, 93 (2): 26-29.

Moore, Danna L. 2003. Survey of Financial Literacy in Washington State: Knowledge, Behavior, Attitudes and Experiences. Technical Report 03-39. Social and Economic Sciences Research Center, Washington State University.

Moschis, George P., and Gilbert A. Churchill Jr. 1978. Consumer Socialization: A Theoretical and Empirical Analysis. Journal of Marketing Research, 15 (4): 599-609.

Murphy, John L. 2013. Psychological Factors and Financial Literacy. Social Security Bulletin, 73 (1): 73-81.

OECD. 2013. Financial Literacy Framework. In PISA 2012 Assessment and Analytical Framework: Mathematics, Reading, Science, Problem Solving and Financial Literacy. Paris: OECD Publishing.

Pinto, Mary Beth, Diane H. Parente, and Phylis M. Mansfield. 2005. Information Learned from Socialization Agents: Its Relationship to Credit Card Use. Family and Consumer Sciences Research Journal, 33 (4): 357-367.

Van Rooij, Maarten, Annamaria Lusardi, and Rob Alessie. 2012. Financial Literacy, Retirement Planning and Household Wealth. The Economic Journal, 122 (560): 449-478.

Van Rooij, Maarten, Annamaria Lusardi, and Rob Alessie. 2011. Financial Literacy and Stock Market Participation. Journal of Financial Economics, 101 (2): 449-472.

Sekita, Shizuka. 2011. Financial Literacy and Retirement Planning in Japan. Journal of Pension Economics and Finance, 10 (4): 637-656. 
Sekita, Shizuka. 2013. Financial Literacy and Wealth Accumulation: Evidence from Japan. Discussion Paper No. 2013-01, Kyoto, Japan: Graduate School of Economics, Kyoto Sangyo University.

Stango, Victor, and Jonathan Zinman. 2009. Exponential Growth Bias and Household Finance. Journal of Finance, 64 (6): 2807-2849.

Hussein A. Hassan Al-Tamimi and Al Anood Bin Kalli. 2009. Financial Literacy and Investment Decisions of UAE Investors. The Journal of Risk Finance, 10 (5): 500-516.

U.S. Financial Literacy and Education Commission. 2007. Taking Ownership of the Future: The National Strategy for Financial Literacy. https://www.treasury.gov/about/organizationalstructure/offices/Domestic-Finance/Documents/Strategyeng.pdf

Ward, Scott. 1974. Consumer Socialization. Journal of Consumer Research, 1 (2): 1-16. 
Table 1: Descriptive Statistics

\begin{tabular}{lrrrrr}
\hline Variable & Obs & Mean & Std. Dev. & Min & Max \\
\hline fliteracy & 1948 & 0.481 & 0.280 & 0 & 1 \\
gender & 1948 & 0.569 & 0.495 & 0 & 1 \\
age & 1948 & 49.305 & 9.879 & 24 & 69 \\
spouse & 1948 & 0.994 & 0.078 & 0 & 1 \\
educ & 1948 & 13.348 & 2.092 & 9 & 21 \\
seduc & 1948 & 13.109 & 1.991 & 9 & 21 \\
feduc & 1948 & 10.986 & 2.350 & 9 & 21 \\
meduc & 1948 & 10.702 & 1.734 & 9 & 17 \\
income & 1948 & 6.662 & 3.861 & 1 & 20 \\
asset & 1948 & 20.918 & 23.565 & 2.5 & 100 \\
emplstatus & 1948 & 0.914 & 0.280 & 0 & 1 \\
occupation & 1948 & 0.030 & 0.171 & 0 & 1 \\
future & 1948 & 2.697 & 0.850 & 1 & 5 \\
finsatisfaction & 1948 & 2.891 & 1.019 & 1 & 5 \\
anxiety & 1948 & 3.474 & 1.070 & 1 & 5 \\
\hline
\end{tabular}


Table 2: Distribution of financial literacy by age, gender, and education

\begin{tabular}{ccc}
\hline \multicolumn{2}{c}{ Variables } & Financial literacy \\
\hline Age & $<40$ years & 0.381 \\
& 40 to 64 years & 0.498 \\
& $>64$ years & 0.474 \\
\hline \multirow{2}{*}{ Gender } & Male & 0.532 \\
& Female & 0.413 \\
\hline Education & $<12$ years & 0.373 \\
& 12 to 16 years & 0.466 \\
& $>16$ years & 0.661 \\
\hline
\end{tabular}


Table 3: Variables and definitions

\begin{tabular}{|c|c|}
\hline Variable & Definition \\
\hline \multicolumn{2}{|c|}{ Dependant variable } \\
\hline Financial literacy & $\begin{array}{l}\text { Financial literacy is measured by four questions related to basic } \\
\text { financial calculation skills and financial instruments. The first question } \\
\text { measures the understanding of compound interest, the second question } \\
\text { measures the understanding of the effect of inflation, the third question } \\
\text { measures the understanding of risk, and the fourth question measures } \\
\text { the understanding of bond pricing behavior. }\end{array}$ \\
\hline \multicolumn{2}{|c|}{ Independent Variables } \\
\hline gender & $1=$ male, $0=$ female \\
\hline age & Respondents' age \\
\hline educ & Years of education \\
\hline Sedu & Years of education of the spouse \\
\hline Fedu & Years of education of respondents' father \\
\hline medu & Years of education of respondents' mother \\
\hline spouse & $1=$ married, $0=$ otherwise \\
\hline emplstatus & $1=$ currently employed $0=$ otherwise \\
\hline occupation & $1=$ working in finance and insurance $0=$ all other occupations \\
\hline Asset & $\begin{array}{l}\text { Balance of financial assets (savings, stocks, bonds, insurance, etc.) of } \\
\text { the entire household }\end{array}$ \\
\hline Income & Household income \\
\hline future & $1=$ respondents who consider the future uncertain, $0=$ otherwise \\
\hline finsatisfaction & $\begin{array}{l}\text { Level of current satisfaction with the family's financial situation. } \\
\text { (minimum }=1 \text {; maximum=5). }\end{array}$ \\
\hline anxiety & $\begin{array}{l}\text { Level of anxiety about life during old age on a five-point scale } \\
\text { (minimum }=1 ; \text { maximum }=5 \text { ). }\end{array}$ \\
\hline
\end{tabular}


Table 4: Regression coefficients

\begin{tabular}{llllll}
\hline & Model 1 & & & Model 2 & \\
\hline fliteracy & Coef. & $\mathrm{t}$ & fliteracy & Coef. & $\mathrm{t}$ \\
\hline gender & 0.093 & $7.69^{* * *}$ & gender & 0.094 & $7.81^{* * *}$ \\
age & 0.003 & $5.17^{* * *}$ & age & 0.013 & $2.45^{* *}$ \\
spouse & 0.017 & 0.23 & age & 0.000 & $-1.83^{*}$ \\
educ & 0.023 & $6.73^{* * *}$ & spouse & 0.016 & 0.22 \\
seduc & 0.009 & $2.72^{* * *}$ & educ & 0.023 & $6.58^{* * *}$ \\
feduc & 0.001 & 0.28 & seduc & 0.009 & $2.60^{* * *}$ \\
meduc & 0.002 & 0.37 & feduc & 0.001 & 0.32 \\
income & 0.009 & $5.83^{* * *}$ & meduc & 0.002 & 0.52 \\
asset & 0.001 & $4.29^{* * *}$ & income & 0.009 & $5.35^{* * *}$ \\
emplstatus & 0.010 & 0.45 & asset & 0.001 & $4.35^{* * *}$ \\
occupation & 0.189 & $5.57^{* * *}$ & emplstatus & 0.005 & 0.26 \\
Future & -0.018 & $-2.60^{* * *}$ & occupation & 0.187 & $5.53^{* * *}$ \\
finsatisfaction & 0.007 & 1.03 & future & -0.017 & $-2.57^{* * *}$ \\
anxiety & 0.003 & 0.57 & finsatisfaction & 0.008 & 1.23 \\
cons & -0.305 & $-2.74^{* * *}$ & anxiety & 0.002 & 0.39 \\
& & & cons & 0.530 & $-3.19^{* * *}$ \\
\hline F & $30.06^{* * *}$ & & F & $28.31^{* * *}$ & \\
Adj. $\mathrm{R}^{2}$ & 17.28 & & Adj. R & 17.39 & \\
Obs. & 1948 & & Obs. & 1948 & \\
\hline
\end{tabular}


Table 5: Robustness check regression coefficients

\begin{tabular}{llllll}
\hline & Model 1 & & & Model 2 & \\
\hline fliteracy_w & Coef. & $\mathrm{t}$ & fliteracy_w & Coef. & $\mathrm{t}$ \\
\hline gender & 0.373 & $7.69^{* * *}$ & gender & 0.379 & $7.81^{* * *}$ \\
age & 0.014 & $5.17^{* * *}$ & age & 0.054 & $2.45^{* * *}$ \\
spouse & 0.068 & 0.23 & Age & 0.000 & $-1.83^{*}$ \\
educ & 0.093 & $6.73^{* * *}$ & spouse & 0.066 & 0.22 \\
seduc & 0.037 & $2.72^{* * *}$ & educ & 0.091 & $6.58^{* * *}$ \\
feduc & 0.004 & 0.28 & seduc & 0.036 & $2.60^{* * *}$ \\
meduc & 0.006 & 0.37 & feduc & 0.004 & 0.32 \\
income & 0.038 & $5.83^{* * *}$ & meduc & 0.009 & 0.52 \\
asset & 0.005 & $4.29^{* * *}$ & income & 0.038 & $5.35^{* * *}$ \\
emplstatus & 0.038 & 0.45 & asset & 0.005 & $4.35^{* * *}$ \\
occupation & 0.756 & $5.57^{* * *}$ & emplstatus & 0.022 & 0.22 \\
future & -0.072 & $-2.60^{* * *}$ & occupation & 0.749 & 0.553 \\
finsatisfaction & 0.027 & 1.03 & future & -0.071 & $-2.57^{* * *}$ \\
anxiety & 0.014 & 0.57 & finsatisfaction & 0.032 & 1.23 \\
cons & -3.879 & $-8.71^{* * *}$ & anxiety & 0.009 & 0.39 \\
& & & cons & -4.781 & $-7.20^{* * *}$ \\
\hline F & $30.06^{* * *}$ & & F & $28.31^{* * *}$ & \\
Adj. R ${ }^{2}$ & 0.172 & & Adj. R ${ }^{2}$ & 0.1739 & \\
Obs. & 1948 & & Obs. & 1948 & \\
\hline & & & & & \\
\hline
\end{tabular}


Table 6: Regression coefficients using instrument variable

\begin{tabular}{llllll}
\hline & Model 1 & & & Model 2 & \\
\hline fliteracy & Coef. & $\mathrm{t}$ & fliteracy & Coef. & $\mathrm{t}$ \\
\hline gender & 0.0941 & $7.64^{* * *}$ & gender & 0.0956 & $7.77^{* * *}$ \\
age & 0.0046 & $1.79^{*}$ & age & 0.0137 & $2.47^{* *}$ \\
spouse & 0.0255 & 0.33 & age & -0.0001 & -1.54 \\
educ & 0.0244 & $5.47^{* * *}$ & spouse & 0.0251 & 0.33 \\
seduc & 0.0096 & $2.75^{* * *}$ & educ & 0.02401 & $5.30^{* * *}$ \\
feduc & 0.0006 & 0.19 & seduc & 0.0093 & $2.64^{* * *}$ \\
meduc & 0.0031 & 0.56 & feduc & 0.0007 & 0.22 \\
income & 0.0100 & $3.75^{* * *}$ & meduc & 0.0037 & 0.69 \\
asset & -0.0003 & -0.09 & income & 0.0100 & $3.40^{* * *}$ \\
emplstatus & 0.0097 & 0.46 & asset & -0.0003 & -0.09 \\
occupation & 0.1944 & $5.40^{* * *}$ & emplstatus & 0.0062 & 0.29 \\
Future & -0.0196 & $-2.50^{* *}$ & occupation & 0.1929 & $5.35^{* * *}$ \\
finsatisfaction & 0.0089 & 1.10 & future & -0.0194 & $-2.47^{* *}$ \\
anxiety & 0.0022 & 0.33 & finsatisfaction & 0.0102 & 1.27 \\
cons & -0.3785 & $-1.94 *$ & anxiety & 0.0012 & 0.19 \\
& & & cons & -0.5823 & $-2.89^{* * *}$ \\
\hline Wald Chi ${ }^{2}$ & $399.55^{* * *}$ & & Wald Chi ${ }^{2}$ & $403.09 * * *$ & \\
$\mathrm{R}^{2}$ & 1664 & & $\mathrm{R}^{2}$ & 0.1679 & \\
Obs. & 1948 & & Obs. & 1948 & \\
\hline
\end{tabular}

